Volume. 8 Nomor. 1, Oktober 2020. p - 2354-8649 I e - 2579-5767

Open Access at: http://ojs.umrah.ac.id/index.php/selat

DOI: https://doi.org/10.31629/selat.v8i1.2791

\title{
IMPLEMENTASI PENGGUNAAN DANA DESA DALAM PELESTARIAN ADAT
}

\author{
Eko Nuriyatman ${ }^{1}$, Windarto ${ }^{2}$, Rustian Mushawirya ${ }^{3}$ \\ 1,2,3Fakultas Hukum Universitas Jambi \\ Jl. Raya Jambi, Muaro Bulian, KM.15, Mendalo Indah Muaro Jambi \\ Korespondensi : ekonuriyatman90@gmail.com
}

\begin{abstract}
This research focuses on the implementation of Village Funds in Jambi Luar Kota Subdistrict, Muaro Jambi Regency in the preservation of customary villages, where villages are autonomous regions with the passing of Law Number 6 of 2014 concerning Villages. The Village Law also provides a breath of fresh air regarding the escape of customary villages, where the previous regulations have not yet brought back the customary village clearly and firmly, but with the emergence of the Village Law it is sufficient to accommodate the Village to continue to maintain and maintain the values of local wisdom. This study uses a descriptive approach, with interview data collection techniques. The Village Adat Institution must be able to cover all aspects, both in terms of customary Village management, supervision of traditional villages, customary Village government to customary Village Regulations, with the presence of Customary Institutions and having a significant role in maintaining and maintaining local cultural values amidst diversity. in society, being able to implement its role without injuring the law, religious values, diversity and so on, but accelerating the realization of an Independent Village without having to erode the original culture of Jambi Luar Kota Subdistrict. The results of this research show that the implementation has been proven proven by ratifying it. The customary institutions in Jambi Luar Kota Subdistrict, it's just not optimal, because the Customary Institution is still focused on internal organizations, customary village regulations and the procurement of Sombolis infentary which is considered one of the local cultural treasures.
\end{abstract}

Keywords; Implementation, Customary Preservation, Local Wisdom.

\begin{abstract}
Abstrak
Penelitian ini terfokus pada Implementasi Dana Desa di Kecamatan Jambi Luar Kota Kabupaten Muaro Jambi dalam pelestarian Desa adat, yang mana desa merupakan daerah otonom dengan disahkannya Undang-Undang Nomor 6 Tahun 2014 Tentang Desa. Undang-Undang Desa juga memberikan angin segar tentang pelestarian mengenai Desa adat, dimana pada regulasi sebelumnya belum memunculkan kembali desa adat secara jelas dan tegas, akan tetapi dengan munculnya Undang-Undang Desa cukup mengakomodir Desa untuk terus menjaga dan mempertahnkan nilai-nilai kearifan lokal. Penelitian ini menggunakan pendekatan deskriptif, dengan teknik pengumpulan data wawancara. Lembaga Adat Desa harus dapat merangkum semua aspek, baik dari segi penataan Desa adat, pengawasan Desa adat, pemerintaha Desa
\end{abstract}


adat sampai pada Peraturan Desa adat, dengan kehadirannya Lembaga Adat serta mendapat peran signifikan dalam menjaga dan mempertahankan nilai-nilai budaya setempat ditengah-tengah keberagaman dalam bermasyarakat, mampu mengimplementasikan perannya tanpa menciderai Undang-Undang, niali-nilai agama, keberagaman dan lain sebagainya, akan tetapi mempercepat terwujudnya Desa Mandiri tanpa harus menkikis budaya asli Kecamatan Jambi Luar Kota.Hasil dari penelitian ini terlihat secra implementasi sudah terwujud terbukti dengan disahkannya Lembaga adat se-Kecamatan Jambi Luar Kota, hanya saja belum maksimal, disebabkan Lembaga Adat masih Fokus pada internal organisasi, peraturan Desa adat dan pengadaan infentaris sombolis yang dianggap sebagai salah satu kekayaan budaya setempat.

Kata Kunci; Implementasi, Pelestarian Adat, Kearifan Lokal.

\section{PENDAHULUAN}

Undang-Undang Nomor 6 Tahun 2014 Tentang Desa (UU Desa) menyebutkan bahwa desa adat atau juga yang disebut dengan nama lainnya (sesuai daerah dan tempat) merupakan suatu kesaturan masyarakat hukum yang pastinya memiliki batas wilayah yang mana mereka berwenang untuk mengatur dan mengurus urusan pemerintahan yang berguna bagi kepentingan masyarakat setempat berdasarkan prakarsa dari masyarakat dan/atau hak tradisional yang yang diakui dan dihormati dalam sistem pemerintahan Negara Kesatuan Republik Indonesia (NKRI). Desa adat yang merupakan suatu Kesatuan Masyarakat Hukum Adat (KMHA) secara konstitusi diatur dialam Pasal 18B ayat (2) Undang-Undang Dasar Neagra Republik Indonesia Tahun 1945 (UUD NRI 1945) yang mana menentukan bahwa KMHA dilindungi serta diakui oleh negara serta terdapat hak tradisional sepanjang hal tersebut masih hidup, berkembang dan sesuai dengan perkembangan dan tidak bertentangan dengan NKRI. Berkaitan denga hal tersenut maka Desa Adat mempunyai hak otonomi di dalam mengatur desa adatnya.

Paul H.Landis mengemukakan mengenai defenisi tentang desa yang mana beliau membagi desa kedalam 3 (tiga) pemilahan berdasarkan kepada tujuan dari analisis, yaitu pertama sebagai sebuah tujuan analisis statistik, yang mana desa didefinisikan sebagai sebuah lingkungan yang penduduknya kurang dari 2500 orang. Kedua, tujuan analisa sosial psikologi, desa merupakan suatu lingkungan yang mana penduduknya memiliki hubungan yang akrab serta serba informal antar sesama 
warganya dan ketiga, sebagai tujuan analisa ekonomi, desa didefinisikan merupakan suatu lingkungan yang mana penduduknya tergantung kepada hasil pertanian. ${ }^{1}$

Selama ini upaya di dalam memperkuat desa selalu mengalami persoalan, dilema dan hambatan, ada beberapa faktor yang menyebabkan hal ini diantarannya adalah dikaranakn mandulnya peran-peran lembaga desa dalam menyambut perubahan yang ada. ${ }^{2}$ UU Desa yang melahirkan adanya gagasan mengenai otonomi desa yang mana hal ini merupakan sebuah gerakan pembaharuan di dalam pengelolaan desa menjadikan lebih modern dan peran dari desa di dalam pembangunan dan fungsi pelayanan terkecil sudah mulai bergerak menuju sebuah kemajuan dan hal ini membuat masa depan desa lebih baik lagi kedepannya. Poin penting mengenai Desa Adat didalam UU Desa terdapat didalam Bab XIII, dimulai dari Pasal 96 sampai dengan Pasal 111, yang mana terdapat dalam hal ini terdapat 16 Pasal dan terdapat 26 ayat yang mengatur mengenai Desa Adat. Otonomi dari Desa Adat terbagi menjadi 3 (tiga), yaitu:

1. Lingkup kewenangan desa adat membentuk aturan hukum adatnya sendiri;

2. Kewenangan desa adat dalam menerapkan dan menyelenggarakan hukum adatnya sendiri;

3. Kewenangan desa adat di dalam menjatuhkan hukumnya sendiri. ${ }^{3}$

Berdasarkan pengertian tersebut dapat disimpulkan bahwa desa adat memiliki kewenangan penuh dan berlaku pada wilayah dan diterapkan pada masyarakat lingkungan itu sendiri, berkaitan dengan hal tersebut maka Desa Adat harus dapat mengelola potensi serta harta kekayaan dari desa adatnya masing-masing. Harta kekayaan Desa Adat yang berwujud dapat berupa tanah adat, keberadaan tanah adat dengan masyarakat adat di wilayah desa adat yang mempunyai hubungan sosial relegius, dalam arti bahwa tanah adat mempunyai fungsi sosial dan relegius bagi mayarakat desa adat. ${ }^{4}$

\footnotetext{
1 Hendra Nurtjahjo dan Fokky Fuad. Legal Standing Kesatuan Mayarakat Hukum Adat, Dalam Berperkara di Mahkamah Konstitusi, Jakarta: Salemba Humanika, 2010, hlm. 40.

2 Muhammad A.Rauf. "Politik Hukum Pembentukan Desa Adat Dalam Sistem Pemerintahan Di Indonesia." Jurnal De Lega Lata, Desember 2016: Vol. 1, No.2, hlm. 414-415.

3 Dewi, "Penyusunan Perda Yang Partisipatif: Peran Desa Pakraman Dalam Pembentukan Peraturan Daerah." Jurnal Zifatama Jawara, 2019, hlm. 126.

${ }^{4}$ Dewa Gede Agung Satria Yoga Purnama dan Anak Agung Istri Ari Atu Dewi, "Desa AdatDalam Pengelolaan Tanah Adat Bali Berbasis Kebijakan Daerah.” Acta Comitas: Jurnal Hukum Kenotariatan, Agustus 2019: Vol.4, No.2, hlm. 345 .
} 
Maka masyarakat adat terdiri atas sebuah kesatuan didalam masyarakat yang memiliki sifat/karakteristik otonom, yang mana mereka mengatur sistim kehidupannya (hukum, politik, ekonomi, dsb). Ia lahir dari, berkembang bersama dan dijaga oleh masyarakat itu sendiri. Berkaitan dengan hal tersebut diatas untuk wilayah Kecamatan Jambi Luar Kota Kabupaten Muaro Jambi yang berkaitan dengan peraturan tentang Desa Adat menghadapi tantangan terbesar disaat berhadapan dengan jumlah desa yang cukup plural dan beragam, serta dihadapi dengan kehidupan saat ini yang cukup modernis masyarakat. Pembentuk dari UU Desa memang perlu untuk mencantumkan poin penting tentang Desa adat yang perlu dijelaskan selain dasar pemikiran, asas pengaturan dan materi muatan, yaitu berupa pengaturan Desa Adat tersebut. Tujuan ini sebenarnya berhubungan dengan pentingnya pengaturan Desa adat dengan pembahasan tersendiri.

Dana Desa yang kita ketahui bahwa tidak sedikit dikucurkan bagi Desa yang berada diseluruh kawasan administratif Indonesia, tidak terkecuali Desa yang berada di Kecamatan Jambi Luar Kota. Beberapa sumber pendapatan desa yaitu misalnya yang berbersumber dari pendapatan asli desa terdiri dari hasil usaha, hasil aset, swadaya dan partisipasi, gotong royong dan lain-lain pendapatan asli desa serta hibah dan sumbangan yang tidak mengikat dari pihak ketiga dan pendapatan lain yang sah, ini menjadikan peluang untuk terealisasinya Desa yang beradat dan bermartabat, tidak terkendala oleh sumber anggaran yang terbatas. Berdasarkan dengan apa yang telah disampaikan pada pendahuluan di atas maka yang akan dibahas didalam artikel ilmiah ini adalah mengenai implementasi dana desa terkait Desa Adat di Kecamatan Jambi Luar Kota Kabupaten Muaro Jambi.

Berdasarkan hal tersebut diatas maka tinjauan pustaka yang terkait dengan artikel ilmiah ini adalah mengenai implementasi, pembangunan desa dan desa adat. Implementasi merupakan suatu proses untuk melaksanakan kegiatan menjadi tindakan kebijakan dari politik kedalam administrasi. ${ }^{5}$ Dalam hal ini pengembangan suatu kebijakan dalam rangka penyempurnaan suatu program. Sedangkan menurut Guntur Setiawan mengemukakan bahwa implementasi merupakan suatu perluasan aktivitas yang mana saling menyesuaikan proses interaksi antara tujuan dan

\footnotetext{
${ }^{5}$ Harsono dan Hanifah. Implementasi Kebijakan dan Politik. Jakarta: Grafindo Jaya, 2002, hlm. 67.
} 
tindakan untuk mencapainya serta memerlukan jaringan pelaksana, birokrasi yang efektif. ${ }^{6}$

Pembangunan sendiri dapat pula diartikan sebagai suatu kegiatan usaha sadar di dalam rangkaian kegiatan untuk dapat mencapai suatu perubahan dari suatu keadaan yang buruk menuju kepada yang lebih baik dan dilakukan oleh masyarakat tertentu pada suatu negara. Pembangunan merupakan suatu usaha atau serangkaian usaha pertumbuhan dan perubahan yang berencana yang dilakukan secara sadar oleh suatu bangsa, negara dan pemerintahan dalam usaha pembinaan bangsa. ${ }^{7}$ Pada konsep pembangunan ini terdapat 2 (dua) syarat yang harus dipenuhi, yaitu harus ada usaha yang dilakukan oleh masyarakat dan pemerintahnya, dilaksanakan secara sadar, terarah dan berkesinambungan agar tujuan dari pembangunan tersebut dapat tercapai.

Desa adat tergolong menjadi 4 (empat) bagian, yaitu penataan desa adat, kewenangan desa adat, pemerintah desa adat dan peraturan desa adat. Berkaitan dengan hal tersebut Desa Adat pada prinsipnya merupakan suatu warisan organisasi didalam kepemerintahan masyarakat lokal yang mana dipelihara secara turuntemurun yang tetap diakui serta diperjuangkan oleh pemimpin dan masyarakat Desa Adat agar dapat berfungsi mengembangkan kesejahteraan dan identitas sosial budaya lokal.

\section{METODE PENELITIAN}

Metode penelitian yang digunakan didalam artikel ilmiah ini adalah yuridis empiris dengan menggunakan pendekatan deskriptif, kemudian teknik pengumpulan data dilakukan dengan mewawancarai narasumber yang dianggap representatif yang benar-benar mewakili sifat populasi. Sehingga diperoleh hasil yang bisa dipertanggung jawabkan secara ilmiah. Metode penelitian empiris ini dimana proses pengumpulan data dan analisis berlangsung selama dan paska pengumpulan data, proses analisis berlangsung dari tahap awal sampai dengan tahap penarikan kesimpulan hasil studi. ${ }^{8}$ Analisis data didalam yuridis empiris ini sebagai model alir

6 Guntur Setiawan. Implementasi Dalam Birokrasi Pembangunan. Bandung: Remaja Rosdakarya Offset, 2004, hlm. 39.

${ }^{7}$ Siagian, P.S. Teori dan Praktek Kepemimpinan. Jakarta: Rineka Cipta, 1991, hlm. 21.

${ }^{8}$ Agus Salim. Teori Paradigma Penelitian Sosial, Yogyakarta: Tiara Wacana, 2006, hlm. 22. 
(flow model), yang mana terdiri dari pengumpulan data, reduksi data (data reduction), penyajian data (data display) dan penarikan kesimpulan serta verifikasi (conclusion drawing and verification).

\section{PEMBAHASAN}

Van Vollenhoven mengatakan bahwa masyarakat asli dan yang hidup di Indonesia, semenjal ratusan tahun sebelum datangnya Belanda, telah memiliki sebuah kehidupan beserta dengan tatananya yang mana tatanan ini dikenal dengan yang namanya hukum adat. ${ }^{9}$ Prespektid dari hukum adat itu sendiri sesungguhnya merupakan sebuah hukum yang asli (Melayu Polenesia) serta ditambah dari ketentuan yang ada didalam Agama. ${ }^{10}$ Maka dari itu adanya Undang-Undang Desa hadir dengan memperkuat status sebagai dari penguatan dari masyarkat dan juga sebagai sebuah kekuatan untuk dapat membangun infrastruktur yang ada didesa beserta dengan pemberdayaan masyarakat desa, maka perlu dibarengi dengan aturan teknis yang mana mengatur pengelolaan terhadap keuangan secara transparansi dan akuntabilitas.

Maka dari itu hukum adat dapat diartikan sebagai keputusan yang diberikan oleh para pejabat hukum, baik hakim desa kerapatan desa, pejabat agama serta pejabat desa yang memiliki kewibawaan serta harus dapat dipatuhi oleh seluruh masyarakat hukum adat. Keputusan tersebut memiliki nilai kerohanian (religiousmagis) dan memiiki nilai-nilai kemasyarakatan yang hidup dan tumbuh di tengahtengah masyarakat. ${ }^{11}$ Seperti itu pula dengan yang tinggal dan yang ada di Provinsi Jambi. Provinsi Jambi sebagaimana desa merupakan persekutuan hukum adat yang ada di Indonesia juga mengenal mengenai tanah hak ulayat yang disebut hak ulayat marga dan tanah desa. Menurut Rossa Candra Budy selaku Camat Kecamatan Jambi Luar Kota membenarkan hal tersebut, sehingga dengan berlakunya UU Desa yang mana salah satunya mengatur tentang keberadaan kembali Desa Adat menjadi sesuatu yang positif dan memiliki budaya yang masih cukup kental.

\footnotetext{
9 Hendra Nurtjahjo dan Fokky Fuad, Legal Standing Kesatuan Mayarakat Hukum Adat, dalam berperkara di Mahkamah Konstitusi, Salemba Humanika, Jakarta, 2010, hlm. 40.

10 Bewa Ragawino, Pengantar Dan Asas Asas Hukum Adat Di Indonesia, FISIP UNPAD, Bandung, 2010, hlm. 8.

11 Hendra Nurtjahjo dan Fokky Fuad, Op., Cit. Ibid., hlm. 10.
} 
Kecamatan Jambi Luar kota memiliki sembilan belas Desa namun dengan berlakunya UU Desa ini maka setiap desa harusnya dapat memuat Desa Adat sebagat salah satu keunikan dan kekhasan dari masing-masing desa tersebut. Setelah berlakunya UU Desa sampai dengan saat ini baru terdapat 4 (empat) Desa yang mengimplementasikannya sesuai dengan Pasal 96 sampai dengan Pasal 111 yaitu dimulai dari penataan, kewenangan, pemerintahan Desa Adat dan Perturan Desa adat. Hal tersebut mengindikasikan bahwa secara keseluruhan Kecamatan Jambi Luar Kota tidak terlalu mempermasalahkan adanya Desa Adat dan masih seperempat dari seluruh desa yang anda untuk mengakomodir mengenai Desa Adat tersebut sesuai dengan amanat UU Desa. Kekurangan ini salah satunya disebabkan oleh faktor sejarah yang mendorong mereka sudah memiliki kekayaan adat yang luar biasa dan diperkuat hadirnya pembahasan khusus tentang Desa Adat sepanjang tidak bertentangan dengan ketentuan peraturan perundang-undangan.

Berkaitan dengan pengakuan oleh negara terhadap sebuah sistem pemerintahan berkaitan dengan Desa Adat yang mana dalam perkembangannya sangatlah dipengaruhi oleh produk hukum nasional di dalam mengatur sebuah kehidupan masyarakat dalam hal ini adalah masyarakat Desa Adat. Urgensi dari hadirnya negara untuk dapat mengakui Desa Adat pada sistem Pemerintahan Indonesia yang merupakan sebuah cita-cita para pendiri bangsa adalah untuk dapat memberikan kejelasan dari sebuah kedudukan dan tujuan terbentuk-nya desa yang lebih mandiri dengan modal sosial yang kuat. Adapun penjelasan mengenai 4 (empat) hal tersebut adalah seagai berikut:

\subsection{Penataan Desa Adat Kecamatan Jambi Luar Kota}

Lembaga Adat Desa yang tersebar di Kecamatan Jambi Luar Kota merupakan kesatuan organisasi kemasyarakatan yang disepakati bersama oleh masyarakat Desa setempat, yang mempunyai wilayah kajian tertentu terkait nilai-nilai keraifan lokal Desa setempat, serta berhak dan berwenang untuk dapat mengatur dan mengurus serta menyelesaikan hal-hal yang berkaitan dengan adat asal dirasa tidak bertentangan dengan Undang-Undang dan Agama. Lembaga adat yang berada di seluruh Desa Kecamatan Jambi Luar Kota tidak berdiri sendiri, melainkan harus mampu bekerja sama dengan berbagai lembaga dan instansi pemerintahan lainnya di 
berbagai lini dan tingkatan, termasuk dengan semua perangkat Desa sampai pada tataran tingkat provinsi.

Lembaga Adat Desa yang ada di Kecamatan Jambi Luar Kota sudah ada dan dikukuhkan langsung oleh Bupati Kabupaten Muaro Jambi, akan tetapi masih ada Desa yang belum terliah kinerja Lembaga Adatnya. Sampai saat ini penataan terus dilakukan salahsatunya keterlibatan Lembaga Adat Kabupaten Muaro Jambi memberikan sosialisai diseluruh Desa yang ada di Kecamatan Jambi Luar Kota. Maka dari itu kejelasan terhadap status serta kepastian hukum, pengakuan dan penghormatan, memberdayakan desa, dalam pembangunan nasional. ${ }^{12}$ Setelah itu Desa Adat wajib untuk didaftarkan dengan tujuan untuk dapat memperoleh pengakuan serta kepastian akan menerima dana bantuan pemberdayaan Desa sebagaimana yang dijelaskan didalam Undang-Undang Desa Desa dan Peraturan Pemerintah Nomor 43 Tahun 2014 tentang Peraturan Pelaksanaan Undang-Undang Desa, maka harus dipertimbangkan beberapa konsekuensi hukum yang akan timbul dan menjadi masalah.

Maka Proses terhadap Desa Adat dalam ketentuan Peraturan Pemerintah Nomor 43 Tahun 2014 menyebutkan harus dilakukan melalui identifikasi dan pengakajian yang dilakukan secara bersama antara Pemerintah Provinsi dan Pemerintah Kabupaten dan sebelum Peraturan Daerah tentang penetapan kampung adat ditetapkan oleh Kepala Daerah. ${ }^{13}$ Maka hal ini perlu dilakukan kebijakan oleh pemerintah daerah untuk dapat memberikan kepastian hukum pada desa-desa adat di Kecamatan Jambi Luar Kota.

\subsection{Kewenangan Desa Adat Kecamatan Jambi Luar Kota}

Kewenangan Desa Adat terdapat didalam Peraturan Menteri Dalam Negeri Republik Indonesia Nomor 44 Tahun 2016 Tentang Kewenangan Desa, yang mana Pasal 4 mengenai ruang ligkup terhadap desa adat dan Bab V mengatur mengenai kewenangan yang domiliki terhadap desa adat tersebut, Kewenangan Desa Adat berdasarkan hak asal usul, secara khsusus dijelaskan lagi lebih gambang dalam Pasal

12 Abd. Hadi, "Desa Adat Dalam Sistem Ketatanegaraan Republik Indonesia Sebagai Implikasi Hukum Setelah Berlakunya UU NO. 6 Tahun 2014 Tentang Desa," Dih Jurnal Ilmu Hukum, Agustus 2017: Vol.13, No.26, hlm. 170.

13 Muammar Alkadafi, dkk, "Kebijakan Penetapan Pemerintahan Kampung Adat di Kabupaten Siak Provinsi Riau," Jurnal El-Riyasah, April 2019: Vol.10, No.1, hlm. 5. 
103 Undang-Undang Desa, yang diantaranya meliputi pengaturan dan pelaksanaan pemerintahan berdasarkan susunan asli, pengaturan dan pengurusan ulayat atau wilayah adat, dan pelestarian nilai sosial budaya Desa Adat. Yang operasionalnya diperjelas dalam Pasal 3 Peraturan Menteri Desa Nomor 1 tahun 2015 Tentang Pedoman Kewenangan Berdasarkan Hak Asal Usul dan Kewenangan Lokal Berskala Desa.

Maka dari iru kewenangan desa yang lebih luas diberikan peraturan perundang-undangan menjadikan desa memiliki tata pemerintahan layaknya Kabupaten/Kota. Salah satu pembahasan utama yang harus diperhatikan adalah apa saja kewenangan yang dimiliki oleh Desa dan bagaimana peraturan desa itu sendiri. ${ }^{14}$ Berdasarkan hal tersebut maka penetapan terhadap kewenangan lokal berskala desa menjadi kewenangan desa melalui undang-undang.

Untuk desa-desa di Kecamatan Jambi Luar Kota terdapat beberapa istilah dalam adat Melayu Jambi yaitu pertama "adat yang teradat," yang merupakan suatu kebiasaan yang tidak dapat dihindari atau ditinggalkan, kedua "adat yang diadatkan," merupakan suatu kebiasaan yang berjalan menurut masanya, ketiga "adat istiadat," yang mana mengacu kepada adat yang dicari-cari, aturan yang "di-dalak-dalak" oleh nenek moyang yang dianggap baik dan patut untuk dipakai dan dijadikan eco pakai oleh di kemudian hari. Khusus di Kecamatan Jambi Luar Kota mayoritas masih terfokus kepada penanganan kasus-kasus sosial yang dirasa merusak tatanan budaya bermasyarakat serta pada lingkup pengadaan infentaris budaya, seperti pelestarian baju adat dan simbol-simbol adat lainnya yang dirasa merepresentatifkan masyarakat Desa setempat.

Salah satu kasus yang baru saja dihadapkan pada Desa Jaluko, yaitu terkait dengan pelanggaran adat yaitu adanya sebuah temuan perselingkuhan oleh warga, yang kemudian diselesaikan dengan cara adat oleh Lembaga Adat Desa Jaluko, dengan kewenangan yang dimiliki serta disahkan dengan adanya kesepakatan dari kedua belah pihak tidak maka kejadian ini tidak perlu diselesaikan pada ranah hukum Pidana, cukup diselesaikan dengan cara asas kekeluargaan, yang mana pelaku harus menyerahkan satu Ekor Kerbau kepada keluarga yang dirugikan.

14 Lia Sartika Putri, "Kewenangan Desa Dan Penetapan Peraturan Desa," Jurnal Legislasi Indonesia, Juni 2016: Vol.13, No.2, hlm. 167. 


\subsection{Pemerintahan Desa Adat Kecamatan Jambi Luar Kota}

Undang-Undang Desa pada sebuah tataran ilmi hukum memberikan fungsi selft governing community dan juga local self government, sehingga diharapkan kesatuan masyarakat hukum adat yang selama ini merupakan bagian dari wilayah desa, ditata sedemikian rupa menjadi desa dan desa adat. ${ }^{15}$ Maka dari itu salah satu orientasi dengan keberadaan Lembaga Desa ini sebagai suatu Unit Organisasi Pelaksanaan Desa adat, yaitu ketika permasalahan dirasa menganggu kestabilan dalam bermasyarakat dan hal tersebut dirasa dapat diselesaikan cukup melibatkan lembaga adat dan mengantisipasi masalah agar tidak semakin melebar dan lain sebagianya. Lembaga Desa mempunyai posisi strategis untuk saat ini. Pada Kecamtana Jambi Luar Kota setiap Desa kurang lebih dianggarkan berkisar Rp10.000.000,-00 sampai dengan Rp20.000.000,-00 untuk kebutuhan sosialisasi Lembaga Adat dan pengadaan symbol-simbol adat. Idealnya suatu lembaga adat mampu mernunjang kelancaran kegiatan di bidang pemerintahan, pembangunan, dan kemasyarakatan serta memperkuat ketahanan nasional. Maka dari itu identitas lokal pemerintahan desa adat merupakan ciri khas dari bangsa Indonesia yang telah turun temurun diyakini oleh masyarakat desa sebagai sebuah sistem kehidupan sehingga mesti dipertahankan untuk mengembalikan budaya masyarakat yang begitu sakral agar tidak pudar, dan jika suatu bangsa tidak mempunyai ciri khas atau ciri khasnya telah pudar kerena suatu hal, bangsa tersebut akan mengalami perubahan sikap dan tatanan kehidupan yang terjadi pada masyarakatnya.

\subsection{Peraturan Desa Adat Kecamatan Jambi Luar Kota}

Pada dasarnya peraturan dan pengawasan Desa adat harus melibatkan semua steakholder yang terlibat di dalam proses pengawasan agar tujuan awal dari pengadaan Desa Adat dapat terwujud dengan maksimal. Sebaliknya Lembaga Adat Desa pun dilibatkan dalam pengawasan implementasi keuangan Desa. Melalui pengaturan Desa Adat ini diharapkan proses ketahanan nilai adat budaya, agama yang lebih bermartabat, dengan dihadirkannya Lembaga Adat tersebut sebagai wadah untuk mempertahankan nilai-nilai adat budaya lokal Kecamatan Jambi luar

15 Muhammad A.Aruf, "Politik Hukum Pembentukan Desa Adat Dalam Sistem Pemerintahan di Indonesia," De Lega Lata, Desember 2016: Vol. 1, No.2, hlm. 416. 
Kota, tepatnya adat Budaya Melayu Jambi dapat berjalan secara efektif pada proses implemntasinya, sejauh ini peran lembaga adat cukup terlihat dalam memainkan perannya tersebut, walaupun masih seputaran penyelesaian konflik adat, sosialisasi nilai-nilai budaya, dan pengadaan simbol-simbol Budaya, yang terpenting Desa adat tidak mencederai unit-unit lainnya, akan tetapi sebaliknya, mempercepat dan membantu masyarakat Desa yang madani.

\section{PENUTUP}

\subsection{Kesimpulam}

Secara keseluruhan setiap Desa sudah berupaya mewujudkan terbentuknya Desa adat tersebut dengan bantuan dan kontribusi perangkat pemerintahan yang terkait, baik dari Kecamatan, maupun tatanan Kabupaten. Desa berusaha menyeimbangkan antara perencanaan dan implementasi yang berimbang, tahap implementasi Desa adat dirasa prosesnya sedang berjalan dan aparat desa bekerja keras untuk itu, implementasi penggunaan dana Desa terkait Desa adat sudah mulai dirasakan kehadiranya walaupun belum maksimal dalam pelaksanaan implementasi maupun perancanaan yang belum begitu matang, disebabkan masih berputar di penguatan internal Lembaga Adat Desa, kegitan yang mencerminkan kekayaan Budaya Desa, penmyelesaian konflik kedaerahan dan pengadaan simbol-simbol kebudayaan.

\subsection{Saran}

Terdapat 3 (tiga) saran yang peneliti berikan pada artikel ilmiah ini, yaitu mengenai pertama hendaknya seluruh steakholder yang terlibat selalu melakukan komunikasi dan koordinasi yang intens untuk meningkatkan terwujudnya Desa Adat yang sesuai dengan harapan awal, kedua adanya sebuah koordinasi yang berkelanjutan dari daerah administrasi secara horizontal maupun yang vertikal antar administrasi lainnya dan ketiga hendaknya Lembaga Adat Desa terus membenah diri dan memperkuat internal, serta tidak ragu-ragu dalam menjalankan perannya, jika dirasa tidak melanggar nilai ketuhanan, kemanusiaan dan nilai kebernegaraan. 


\section{DAFTAR PUSTAKA}

\section{Buku-buku}

Bewa Ragawino, Pengantar Dan Asas Asas Hukum Adat Di Indonesia. Bandung: FISIP UNPAD, 2010.

Harsono dan Hanifah. Implementasi Kebijakan dan Politik. Jakarta: Grafindo Jaya, 2002.

Hendra Nurtjahjo dan Fokky Fuad, Legal Standing Kesatuan Mayarakat Hukum Adat, Dalam Berperkara Di Mahkamah Konstitusi. Jakarta: Salemba Humanika, 2010.

P.S, Siagian, Teori dan Praktek Kepemimpinan. Jakarta: Rineka Cipta, 1991.

Salim, Agus, Teori Paradigma Penelitian Sosial. Yogyakarta: Tiara Wacana, 2006.

Setiawan, Guntur, Implementasi Dalam Birokrasi Pembangunan. Bandung: Remaja Rosdakarya Offset, 2004.

\section{Artikel}

Abd. Hadi. "Desa Adat Dalam Sistem Ketatanegaraan Republik Indonesia Sebagai Implikasi Hukum Setelah Berlakunya UU NO. 6 Tahun 2014 Tentang Desa." Dih Jurnal Ilmu Hukum. Agustus 2017: Volume 13. Nomor 26.

A.Rauf, Muhammad. "Politik Hukum Pembentukan Desa Adat Dalam Sistem Pemerintahan Di Indonesia." Jurnal De Lega Lata, Desember 2016: Volume 1, Nomor 2.

Dewi, "Penyusunan Perda Yang Partisipatif: Peran Desa Pakraman Dalam Pembentukan Peraturan Daerah." Jurnal Zifatama Jawara, 2019.

Lia Sartika Putri. "Kewenangan Desa Dan Penetapan Peraturan Desa." Jurnal Legislasi Indonesia. Juni 2016: Volume 13. Nomor 2.

Muhammad A.Aruf. "Politik Hukum Pembentukan Desa Adat Dalam Sistem Pemerintahan di Indonesia." De Lega Lata. Desember 2016: Volume 1. Nomor 2.

Muammar Alkadafi, dkk. "Kebijakan Penetapan Pemerintahan Kampung Adat di Kabupaten Siak Provinsi Riau.” Jurnal El-Riyasah. April 2019: Volume 10. Nomor 1.

Purnama, Dewa Gede Agung Satria Yoga dan Dewi, Anak Agung Istri Ari Atu, "Desa AdatDalam Pengelolaan Tanah Adat Bali Berbasis Kebijakan Daerah." Acta Comitas: Jurnal Hukum Kenotariatan, Agustus 2019: Volume 4, Nomor 2.

\section{Peraturan Perundang-undangan}

Undang-Undang Dasar Negara Republik Indonesia Tahin 1945.

Undang-Undang Nomor 6 Tahun 2014 Tentang Desa. 
Peraturan Pemerintah Nomor 43 Tahun 2014 tentang Peraturan Pelaksanaan Undang-Undang Desa.

Peraturan Menteri Dalam Negeri Republik Indonesia Nomor 44 Tahun 2016 Tentang Kewenangan Desa.

Peraturan Menteri Desa Nomor 1 tahun 2015 Tentang Pedoman Kewenangan Berdasarkan Hak Asal Usul dan Kewenangan Lokal Berskala Desa. 